\section{Self-perceptions of Organizational Justice and Burnout in Attitudes and Behaviors in the Work of Internal Auditors}

\author{
Daniele Cristina Bernd \\ Ilse Maria Beuren²
}

\begin{abstract}
Purpose - This study analyzes self-perceptions of justice and burnout in job attitudes and behaviors (job satisfaction, affective organizational commitment, and turnover intentions).
\end{abstract}

Theoretical framework - The literature foresees that perceptions of injustice in the workplace may impact affective organizational commitment (Folger \& Konovsky, 1989), job satisfaction (Folger \& Konovsky, 1989; Cohen-Charash \& Spector, 2001; Colquitt, Conlon, Wesson, Porter, \& Ng, 2001), and turnover intentions (Flint, Haley, \& McNally, 2013; Vaamonde, Omar, \& Salessi, 2018), as well as causing frustration, chronic stress, and burnout (Maslach, 2007).

Design/methodology/approach - A quantitative survey was carried out of internal auditors of companies and a total of 124 valid questionnaires were obtained. The data were analyzed using structural equation modeling.

Findings - The results indicated direct relationships between distributive justice and behavioral variables. They also revealed mediation by burnout in the relationships between procedural justice and both job satisfaction and affective organizational commitment. They also show that auditors who perceive procedural injustice present turnover intentions when they are emotionally exhausted and in a state of depersonalization.

Research Practical \& Social implications - This research shows how perceptions of organizational justice are capable of psychologically influencing individuals into displaying positive behaviors (greater job satisfaction and affective organizational commitment) or dysfunctional behaviors (turnover intentions).

Originality/value - The paper discusses attitudes of initiative and social interaction and passive attitudes arising from exhaustion and indifference to work, and how these can derive from judgments about resource allocation, decision-making processes, and interactions with supervisors.

Keywords - Organizational Justice; Burnout; Job Satisfaction; Turnover Intentions; Affective Organizational Commitment.

1. Federal University of Mato Grosso do Sul, School of Business and Administration, Campus Nova Andradina, MS, Brazil.

2. Federal University of Santa Catarina, Postgraduate Program in Accounting, Florianópolis, SC, Brazil.

\section{How to cite:}

Bernd, D. C., \& Beuren, I. M. (2021). Self-perception of organizational justice and burnout in attitudes and behaviors in the work of internal auditors. Revista Brasileira de Gestão de Negócios, 23(3), p.422-438.
Received on:

07/02/2019

Approved on:

$12 / 02 / 2020$

Responsible Editor:

Prof. Dr. Gina Santos

Evaluation process:

Double Blind Review

Reviewers:

Regina Leite; Ana Paula Marques

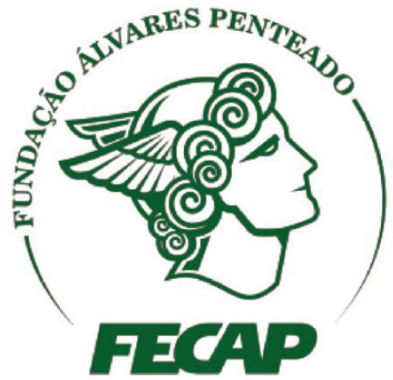

Revista Brasileira de Gestáo de Negócios

https://doi.org/10.7819/rbgn.v23i3.4110 


\section{Introduction}

The perception of organizational justice has proven to be one of the factors that influence employees' attitudes, cognitions, and behaviors towards their organizations and its members (Folger \& Konovsky, 1989; Silva \& Caetano, 2016). In general, organizational justice refers to how employees perceive the justice of the organizational system (Greenberg, 1990). The higher the level of perceived organizational justice, the greater the likelihood of employees feeling they are treated fairly and having positive reactions to the work, supervisors, and results (Moorman, 1991), such as greater trust and affective organizational commitment, better performance at work, increased job satisfaction, and reduced conflicts (Cropanzano, Bowen, \& Gilliand, 2007).

Perceptions of injustice in the workplace can impact affective organizational commitment (Folger \& Konovsky, 1989), job satisfaction (Folger \& Konovsky, 1989; Cohen-Charash \& Spector, 2001; Colquitt, Conlon, Wesson, Porter, \& Ng, 2001), and turnover intentions (Flint, Haley, \& McNally, 2013; Vaamonde, Omar, \& Salessi, 2018). A perception of injustice also has effects that lead to stress (Greenberg, 2004). Employees who do not see their efforts being recognized by the organization may experience frustration and exhaustion (Maslach \& Leiter, 1997; Moliner, Martínez-Tur, Ramos, Peiró, \& Cropanzano, 2008). Their need for recognition and career advancement can generate chronic stress and burnout (Maslach, 2007).

The present study focuses on burnout syndrome, a psychological condition in which individuals suffer from emotional exhaustion, tend to depersonalize others (co-workers, superiors, clients), and feel low personal accomplishment (Freudenberger, 1974). In addition to having physical and/or mental effects, these factors impact the individual's social relationships with their environment and the organization. As a consequence, they may show counterproductive and dysfunctional attitudes and behaviors that violate organizational norms and jeopardize organizational outcomes (Maslach \& Jackson, 1984). Despite the fact that burnout syndrome is seen as an occupational disease, there is a lack of knowledge on the subject in several professional occupations (BenevidesPereira, 2003).

In the accounting profession, auditing is particularly subject to burnout as it requires a specific set of skills and presents challenges that require the use of various information technologies and attention to changes in regulations. These factors, in addition to reducing the quality of their performance, expose auditors to highly stressful work environments (Kalbers \& Fogarty, 2005). Burnout can adversely influence auditors' work performance and interfere with their job satisfaction, affective organizational commitment, and turnover intentions (Fogarty, Singh, Rhoads, \& Moore, 2000).

Therefore, organizations must be attentive to employees' perceptions of organizational (in)justice, as they can trigger a state of burnout and affect their activities (Maslach \& Jackson, 1984). Despite it being a relevant matter in organizations, few studies have explored the effects of organizational justice on workers' health (Tepper, 2001). And, although it is recognized that these elements tend to negatively affect workers' health and the organization (Almeida \& Silva, 2006), little is known about the factors that cause negative and dysfunctional reactions in stressful jobs, or that lead individuals to a state of burnout (Fogarty et al., 2000).

Previous studies have related the dimensions of organizational justice with only one dimension of burnout (Almeida \& Silva, 2006) or with some specific attitudes or behaviors at work (Filenga \& Siqueira, 2006). Other studies have tested the relationships between organizational justice, burnout, and some functional or dysfunctional behaviors (Campbell, Perry, Maertz, Allen, \& Griffeth, 2013; Shkoler \& Tziner, 2017). In general, these studies have analyzed the relationships between organizational justice, burnout, and organizational behaviors in a fragmented way, in isolated dimensions, or as only constructs.

This gives rise to the following research question: to what extent are organizational justice (in the distributive, procedural, and interactional dimensions), burnout (in the emotional exhaustion, depersonalization, and low personal accomplishment dimensions), and attitudes and behaviors at work (job satisfaction, affective organizational commitment, and turnover intentions) related? The objective is to investigate the self-perception of organizational justice and burnout in the attitudes and behaviors at work of internal auditors. The study analyzes the direct and indirect effects via the mediation of burnout in these interactions.

The study contributes to the literature by investigating the role of organizational justice as an antecedent of burnout and of functional and dysfunctional effects of the individual's attitudes and behaviors at work. Thus, it expands the discussions related to the effects of the perception of organizational justice, its relevance in the 
psychological processes and in the attitudes and behaviors in the work of internal auditors, and the impact of burnout in the organizational context, which is generally explored in the area of occupational health and education. It can also contribute to organizational practice by emphasizing the need to pay greater attention to internal auditors' perceptions of whether their activities and situation are stressful, which can lead to burnout. These two factors can affect the well-being of individuals, their interpersonal relationships, and organizational results, thus requiring preventive action.

\section{Theoretical Framework}

\section{I Organizational justice and burnout}

Organizational justice refers to employees' perception of whether they are treated (un)fairly in their work and other work-related variables can be influenced in this process (Moorman, 1991; Folger \& Cropanzano, 1998). It has been studied as a multidimensional construct, covering the individual, their interactions, and the context in which justice may or may not occur (Colquitt et al., 2001). Different dimensions can be used, but in this study it is assumed that organizational justice is explained by three dimensions: distributive, procedural, and interactional (Moorman, 1991; Cohen-Charash \& Spector, 2001).

Distributive justice refers to distribution of the results achieved (Adams, 1965) and to the justice involved in this (Folger \& Konovsky, 1989). Individuals can react negatively if they perceive inequity, by expressing dysfunctional reactions in the organization (Adams, 1965). Procedural justice is linked to the perception of justice in the organization's formal procedures and the means used to determine these (Folger \& Cropanzano, 1998). Interactional justice focuses on the interpersonal aspect of organizational practices, more specifically on the treatment and communication between superiors and subordinates (Cohen-Charash \& Spector, 2001) and the explanations or justifications given to workers regarding the actions, decisions, and attitudes of managers when they engage in decision-making procedures (Bies \& Moag, 1986).

It is known that workers' perception of (in) justice in the management's distribution of resources, the adoption of procedures, and interpersonal treatment can cause pleasure or suffering at work (Folger \& Cropanzano, 1998). When the individuals perceive that the organizational environment is fair, a range of positive attitudes emerge at both the individual and the organizational levels (Greenberg, 1990). However, feelings of injustice can be negatively reflected in physical, psychological, and behavioral aspects. Individuals exposed to recurrently stressful situations, such as organizational injustice, may develop burnout syndrome (Almeida \& Silva, 2006).

Burnout syndrome is a work-related phenomenon resulting from individuals' prolonged exposure to emotionally demanding factors. It can result from continuous discrepancies in the amount of effort made, interpersonal stress, and jobs where the demands exceed the ability to cope (Maslach \& Jackson, 1984). There is a consensus in the literature that burnout is multidimensional and involves the individual's physical and emotional resources, interpersonal relationships with co-workers, and social elements of self-assessment at work (Maslach, 2007). It involves three characteristics that, individually or jointly, have personal and organizational implications: emotional exhaustion, depersonalization, and low personal accomplishment (Freudenberger, 1974; Maslach, Jackson, \& Leiter, 1996).

Emotional exhaustion, which is considered the main manifestation of burnout, is related to individual aspects that cause stress and involve physical or emotional fatigue, feelings of exhaustion, and a lack of emotional resources to cope with activities, given the excessive demands (Maslach et al., 1996). Depersonalization relates to the interpersonal context, where the individual distances themselves from people as a form of defense against the emotional burden derived from direct contact with others (Maslach, Schaufeli, \& Leiter, 2001). It can lead to a decrease in productivity and the development of negative feelings and reactions towards co-workers and the work (Maslach, 2007). Emotional exhaustion and depersonalization lead to low personal accomplishment, which refers to negative evaluations of the work and the feeling of incompetence and a lack of professional accomplishment (Maslach \& Jackson, 1981).

Previous research indicates that burnout mainly develops in contexts where perceptions of organizational injustice prevail and employees face situations of chronic stress (Moliner, Martínez-Tur, Peiró, Ramos, \& Cropanzano, 2005; Almeida \& Silva, 2006; Moliner et al., 2008; Campbell et al., 2013; Flint et al., 2013; Shkoler \& Tziner, 2017; Vaamonde et al., 2018). In the aforementioned studies, experiencing distributive injustice was positively related to burnout (Tepper, 2001). Employees can perceive 
distributive injustice when they feel they invest more in their work than they are rewarded (Colquitt et al., 2001).

A lack of recognition of their efforts generates frustration, which can culminate in exhaustion (Maslach \& Leiter, 1997), anxiety, depression, and a sense of threat to the individual's self-efficacy (Tepper, 2001). Feeling of helplessness and lack of control result from distorted perceptions of the recognition of efforts and, as a consequence, lead to negative attitudes and feelings of depersonalization towards coworkers and the organization (Lewin \& Sager, 2007). Thus, it is assumed that the unfair distribution of resources can lead to burnout syndrome (emotional exhaustion, depersonalization, and low personal accomplishment), and so the first hypothesis is formulated and subdivided into three dimensions:

$\mathbf{H}_{1 \mathbf{a}}$ : Distributive justice is negatively related to burnout.

Perceptions of procedural (in)justice are also reflected in the development of burnout. A lack of feedback, control, and autonomy, uncertainty about organizational processes, and little participation in decision making are associated with the three dimensions of burnout (Maslach et al., 2001). A lack of energy and enthusiasm resulting from the perception that formal management processes directly impact professional routines can lead to emotional exhaustion due to an overload of tasks, pressures, and interpersonal conflicts in the workplace. It can also be reflected in hostile attitudes, harsh behaviors, and indifference towards others and the organization, which are typical of depersonalization (Maslach \& Goldberg, 1998). Professional non-fulfillment can result from an imbalance between the worker's expectations and the procedural injustice employed (Moliner et al., 2005), not having a voice in organizational processes, and an ambiguity of roles (Lewin \& Sager, 2007). Based on these arguments, it is assumed that individuals can develop burnout (emotional exhaustion, depersonalization, and low personal accomplishment) if they believe that organizational processes are unfair: burnout.

$\mathbf{H}_{1 \mathbf{b}}$ : Procedural justice is negatively related to

A perception of interactional justice fosters better interpersonal relationships between subordinates and supervisors. However, when supervisors retain important information (Tepper, 2001) and there is a feeling of not being part of the organization, negative and harmful experiences can occur in these social interactions. These include tensions and an increased feeling of exhaustion
(Moliner et al., 2008), colder, impersonal, or insensitive attitudes (which are typical of depersonalization) (Maslach \& Goldberg, 1998), a lack of motivation, and personal and professional dissatisfaction (reduced accomplishment) (Maslach \& Jackson, 1981). Thus, it is assumed that the higher the level of organizational justice that individuals perceive in the work environment, the lower the occurrence of burnout (emotional exhaustion, depersonalization, and low personal accomplishment).

$\mathbf{H}_{1 \mathbf{c}}$ : Interactional justice is negatively related to burnout.

\subsection{Burnout and attitudes and behaviors at work}

In addition to the health, physical, and psychological impacts on the individual, burnout syndrome affects attitudes and behaviors, which often become dysfunctional, as well as relationships and organizational results (Kalbers $\&$ Fogarty, 2005). Individuals who develop burnout stop taking the usual amount of care and may produce lowerquality work if they withdraw psychologically from the organization (Fogarty et al., 2000).

The main impacts of burnout on the organization are poorer-quality work, absenteeism, turnover intentions, and actual turnover (withdrawal from the organization). Those who remain in their positions but are affected by the dimensions of burnout show reduced productivity and effectiveness at work. Burnout may cause negative effects on job satisfaction and commitment to activities and/or to the organization, generating greater interpersonal conflicts and interruptions in work tasks (Maslach et al., 2001). According to these authors, burnout has been conceived as a form of stress at work that affects job satisfaction, organizational commitment, and turnover.

Job satisfaction can be understood as an emotional or affective response to assessments of different factors in the work context (Locke, 1984). It has been recognized as a factor that can be negatively influenced by burnout (Scanlan \& Still, 2013). Individuals who suffer from emotional exhaustion, depersonalization, and/or low personal accomplishment at work tend to experience a lack of job satisfaction (Maslach \& Jackson, 1981; Kuo, Lin, $\& \mathrm{Li}, 2014)$, as they assess themselves negatively and feel dissatisfied with themselves and with their achievements at work (Maslach \& Jackson, 1981).

Turnover intentions may be a consequence of burnout. This is considered to be the last stage of withdrawal 
cognitions, which consist of thoughts of quitting and looking for another job (Tett \& Meyer, 1993). Turnover generates costs and can negatively influence internal and external social relations, causing discouragement and lowering productivity. Previous research has found a positive relationship between burnout and turnover intentions (Lee \& Ashforth, 1996; Kuo et al., 2014).

Affective organizational behaviors are also linked to burnout. They relate to affective or emotional states of identification with the target of one's commitment (Meyer, Allen, \& Smith, 1993) and the desire to maintain bonds with and defend one's organization (Mowday, Steers, \& Porter, 1979; Leiter \& Maslach, 2005). The results of the study conducted by Leiter and Maslach (2005) reveal that a high level of burnout is related to low organizational commitment and aspects of the organization's interpersonal environment.

Lee and Ashforth (1996) observed that all of the dimensions of burnout are negatively related to job satisfaction and organizational commitment, and positively related to turnover intentions. Thus, the present research suggests that individuals in a state of burnout will be directly affected by attitudes and behaviors at work, which include: (i) reduced job satisfaction; (ii) affective organizational commitment; and (iii) increased turnover intentions (Kahill, 1988). Thus, the second hypothesis is proposed, subdivided into three dimensions:

$\mathbf{H}_{2}$ : Burnout is related to attitudes and behaviors at work: it is negatively related with job satisfaction $\left(\mathrm{H}_{2 \mathrm{a}}\right)$, negatively related with affective organizational commitment $\left(\mathrm{H}_{2 b}\right)$, and positively related with turnover intentions $\left(\mathrm{H}_{2 \mathrm{c}}\right)$.

\subsection{Interactions between organizational justice, burnout, and attitudes and behaviors at work}

Organizational justice can explain employees' attitudes and behaviors in an organization (Folger \& Konovsky, 1989; Greenberg, 1990). Previous studies have identified consequences for organizations and their members (Folger \& Cropanzano, 1998) and these studies believe that it is important to study organizational justice as a predictor of attitudes and behaviors at work (Cohen-Charash \& Spector, 2001; Colquitt et al., 2001). Perceptions of (in)justice have attitudinal responses to job satisfaction, commitment, and trust in supervisors, and behavioral responses to organizational citizenship, aggression in the work environment, and turnover (Folger \& Konovsky, 1989).

In their research, Folger and Konovsky (1989)

found a positive association between distributive justice and job satisfaction. This interaction occurs as individuals perceive a balance between their efforts and income, with a consequent increase in job satisfaction and fewer intentions to withdraw from the organization (Colquitt et al., 2001). Cohen-Charash and Spector (2001) identified a positive relationship between both procedural and distributive justice and job satisfaction. Choi (2011) observed a positive relationship between the dimensions of distributive, procedural, and interactional justice and job satisfaction.

Vaamonde et al. (2018) found that the dimensions of organizational justice are negatively related to turnover intentions. Previous studies show relationships with perceptions of distributive injustice (Colquitt et al., 2001). Flint et al. (2013) identified negative relationships in the procedural and interpersonal dimensions and that both are related to social exchange phenomena (involving the organization and superiors). These perceptions can motivate employees to leave the organization when their interactions lead to self-perceptions of injustice.

Filenga and Siqueira (2006) identified perceptions of organizational justice as an antecedent of organizational commitment. Previous research has revealed that perceptions of receiving fair wages, respectful treatment, and consideration and of having a voice in the organization are related to affective commitment. In this case, the employee identifies more with the organization and creates emotional ties with it (Colquitt et al., 2001).

In addition to the direct impacts on behavioral variables, each dimension of organizational justice plays a different role in the stress process (Greenberg, 2004). According to Robbins, Ford, and Tetrick (2012), perceptions of injustice are a symptom of high efforts for low rewards, in which employees are subjected to demanding situations without being rewarded, due to the procedures in place, or they are treated interpersonally with disrespect. Individuals who feel that their efforts are not recognized by the organization may be affected by burnout (Maslach \& Leiter, 1997; Moliner et al., 2008). Thus, organizational injustice can represent a stress factor, which mediates the effect of the characteristics of and experiences at work (Cropanzano, Goldman, \& Benson, 2005).

In this context, burnout acts as a mediating variable, as it influences the magnitude of the relationships 
between organizational justice and behaviors at work. Thus, the third hypothesis was formulated:

$\mathbf{H}_{3}$ : Burnout mediates the relationship between organizational justice and attitudes and behaviors at work (job satisfaction, affective organizational commitment, and turnover intentions).

Figure 1 illustrates the theoretical model proposed in this study.

It is assumed that organizational injustice (distributive, procedural, and interactional) can lead to increased levels of burnout (emotional exhaustion, depersonalization, and low personal accomplishment) $\left(\mathrm{H}_{1}\right)$ and reduced job satisfaction, less affective organizational commitment, and greater turnover intentions $\left(\mathrm{H}_{3}\right)$. On the other hand, lower levels of burnout can lead to more positive attitudes and behaviors, such as greater job satisfaction, affective organizational commitment, and lower turnover intentions $\left(\mathrm{H}_{2}\right)$.

\section{Methodology}

\section{I Sample selection and data collection}

A quantitative study was conducted using internal auditors of Brazilian companies, from December 2014 to February 2015. The research population was identified in the following professional entities: Instituto de Auditores Internos no Brasil - IIA Brasil (Brazilian Institute of Internal Auditors), Grupo de Auditores Internos (Internal Auditors Group), Grupo de Auditoria Interna, Controles Internos e Gestão de Riscos (Internal Auditing, Internal Controls, and Risk Management Group), and Grupo de Auditores
Internos do Paraná- GAIP (Group of Internal Auditors of Paraná). A link to the questionnaire on the Google Docs platform was sent to the 450 internal auditors identified, resulting in 124 valid responses.

The responses obtained came from professionals in 13 Brazilian states. About 38\% of them work in Paraná, 13\% in São Paulo, 10\% in Ceará, 9\% in Mato Grosso, and 4\% in each of the states of Santa Catarina, Rio de Janeiro, and Minas Gerais. $73 \%$ of the respondents are male, they have an average age of 35, and most have a lato sensu postgraduate degree (65\%). Regarding their position in the companies, there was a predominance of management positions $(35 \%)$ and analysts (27\%), and about $30 \%$ indicated other positions: senior auditors, staff auditors, coordinators, directors, partners, supervisors, and superintendents. Regarding their time working for the companies, $47 \%$ of the respondents stated that they had been in the same company for more than five years. These companies are in 16 different economic segments, ranging from industrial to agro-industrial segments. These demographic data reveal the heterogeneous characteristics of the respondents and meet the conditions required to form part of the research sample.

\subsection{Measurement of research constructs}

The constructs were measured using a seven-point Likert scale (Appendix A). Some precautions were taken in order to reduce biases that could compromise the validity of the answers: (i) the instruments contained both positive and negative statements and reverse questions in order to keep the respondents attentive; (ii) the questions were presented in a variety of ways; (iii) each construct presented different responses, for example $(0=$ totally disagree $/$ never

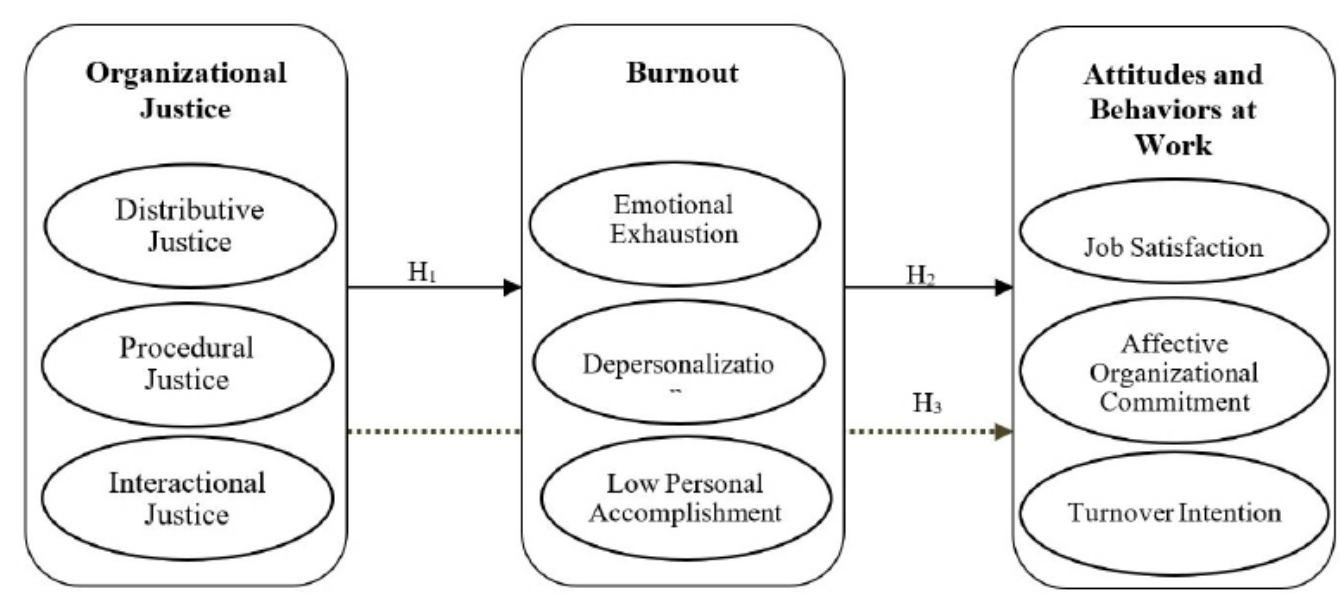

Figure 1. Theoretical model and hypotheses of the research 
/ none; 6 = totally agree / every day / all the time); and (iv) the anonymity of the respondents and the companies they work for was ensured to avoid embarrassment or bias in the responses (Scheaffer, Mendenhall, \& Ott, 1996).

Self-perception of organizational justice was measured using the Organizational Justice Perception Scale (OJPS), which was validated by Mendonça, Pereira, Tamayo, and Paz (2003). It included sentences about aspects of the work ( 0 = strongly disagree; $6=$ strongly agree), in the following dimensions: distributive ( 6 items), procedural (7 items), and interactional (7 items). The reliability of this construct was reflected in a Cronbach's alpha of 0.964 . Exploratory factor analysis (EFA) generated a two-factor model, covering distributive justice and procedural justice (in which the procedural and interactional items were grouped together). The literature suggests that interactional justice can be considered a branch or a social form of procedural justice (Cropanzano \& Greenberg, 1997). Two statements that affected the model were excluded. Together, these two constructs represent $70.89 \%$ of the total variance explained and present a KMO of 0.930 , thus indicating internal consistency.

The Maslach Burnout Inventory - General Survey (MBI-GS) was used to measure the burnout construct in several occupational contexts (Maslach et al., 2001) in the following dimensions: emotional exhaustion (6 items), low personal accomplishment (6 reverse items), and depersonalization ( 4 items). Each of the statements was meant to assess feelings related to the work $(0=$ never; $6=$ every day). This construct had a Cronbach's alpha of 0.904 , total variance explained of $66.73 \%$, and $\mathrm{KMO}$ of 0.829 .

For the behavior at work construct, the respondents were asked to indicate a number representing the occurrence of situations related to coping, routines, and attitudes towards the current work. The Hoppock instrument (1935) was used, including three items, to measure job satisfaction. This resulted in a Cronbach's alpha of $0.757, \mathrm{KMO}$ of 0.624 , and total variance explained of $68.43 \%$. Turnover intentions were measured by four items, adapted from the instrument of Mobley, Horner, and Hollingsworth (1978) and Lee (1996). After excluding one statement that affected the model (ITN4, Appendix A), it had a Cronbach's alpha of 0.917, total variance explained of $85.90 \%$, and $\mathrm{KMO}$ of 0.709 . Affective organizational commitment was measured using the research instrument of Meyer et al. (1993). According to the EFA, two factors were formed, called emotional connection (3 reverse items: $\mathrm{COA} 3, \mathrm{COA} 4$, and $\mathrm{COA} 5$ ) and significance ( 3 items: COA1, COA2, and COA6). Together, they had a Cronbach's alpha of $0.751, \mathrm{KMO}$ 0.737 , and total variance explained of $67.53 \%$.

\subsection{Procedures for the data analysis}

Non-response bias tests were applied to validate the information obtained through the research instruments. Initially, the first-last method was adopted (comparing the averages of the first 10 responses with the last 10) and there were no statistically significant differences in any of the constructs (p-values between 0.236 and 0.678 ). The same occurred when analyzing the 62 initial and 62 final responses (p-values between 0.241 and 0.832). Then, reliability and EFA tests were conducted using Harman's single factor test to analyze common method bias. The total variance explained for a single factor was $71.40 \%$, suggesting that there is no common method bias. This indicates that the instruments did not cause variations in the responses, and that the existence of noise did not affect the data and any inferences derived (Podsakoff, MacKenzie, Lee, \& Podsakoff, 2003).

The data were analyzed with Structural Equations Modeling (SEM) estimated via Partial Least Squares (PLS), using the SmartPLS software. PLS-SEM is most recommended when trying to explain the variation between the dependent variables of a model, due to its ability to estimate coefficients that maximize the $\mathrm{R} 2$ values of the independent constructs (Hair Jr, Hult, Ringle, \& Sarstedt, 2016). The recommendations of Baron and Kenney (1986) and Hayes (2013) to analyze the direct, indirect, and total effects of the model based on bootstrapping were used to analyze the mediation. The Sobel test was also carried out to confirm the measurements found in the model, by analyzing the coefficients and errors of the indirect effects.

\section{Results Analysis}

\section{I Evaluation of the measurement model}

The validation of the reflective measurement models (Table 1) confirms the convergent validity of the model through the average variance extracted (AVE), since all the AVE coefficients are above 0.50 (Hair Jr et al., 2016). According to the criteria of Fornell and Larcker (1981), discriminant validity is also attested when evaluating the values of the diagonal of each construct and if it is 
Table 1

Results of the measurement model and descriptive statistics $(n=124)$

\begin{tabular}{|c|c|c|c|c|c|c|c|c|c|}
\hline Constructs & 1 & 2 & 3 & 4 & 5 & 6 & 7 & 8 & 9 \\
\hline 1. DJ & 0.870 & & & & & & & & \\
\hline 2. PJ & $0.755^{* *}$ & 0.817 & & & & & & & \\
\hline 3. $\mathrm{EE}$ & $-0.357^{* *}$ & $-0.431^{* *}$ & 0.828 & & & & & & \\
\hline 4. DEP & $-0.251^{*}$ & $-0.306^{* *}$ & $0.629^{* *}$ & 0.834 & & & & & \\
\hline 5. LPA & $-0.227^{*}$ & $-0.284^{* *}$ & $0.352^{* *}$ & $0.441^{* *}$ & 0.747 & & & & \\
\hline 6. JOS & $0.452^{* *}$ & $0.444^{* *}$ & $-0.510^{* *}$ & $-0.416^{* *}$ & $-0.604^{* *}$ & 0.826 & & & \\
\hline 7. TNI & $-0.492^{* *}$ & $-0.455^{* *}$ & $0.654^{* *}$ & $0.661^{* *}$ & $0.380^{* *}$ & $-0.548^{* *}$ & 0.927 & & \\
\hline 8. ACEC & 0.189 & $0.285^{* *}$ & $-0.513^{* *}$ & $-0.542^{* *}$ & -0.128 & $0.316^{* *}$ & $-0.510^{* *}$ & 0.824 & \\
\hline 9. ACM & $0.411^{* *}$ & $0.426^{* *}$ & $-0.464^{* *}$ & $-0.466^{* *}$ & $-0.441^{* *}$ & $0.548^{* *}$ & $-0.536^{* *}$ & $0.373^{* *}$ & 0.799 \\
\hline AVE & 0.756 & 0.667 & 0.685 & 0.695 & 0.558 & 0.682 & 0.859 & 0.68 & 0.639 \\
\hline Composite Reliability & 0.949 & 0.960 & 0.928 & 0.901 & 0.883 & 0.863 & 0.948 & 0.863 & 0.840 \\
\hline Cronbach's Alpha & 0.935 & 0.954 & 0.907 & 0.854 & 0.846 & 0.763 & 0.917 & 0.767 & 0.722 \\
\hline Mean & 4.70 & 4.79 & 3.27 & 2.45 & 2.13 & 5.42 & 2.85 & 5.41 & 5.03 \\
\hline Standard Deviation & 1.47 & 1.38 & 1.35 & 1.45 & 0.78 & 0.95 & 1.86 & 1.37 & 1.39 \\
\hline
\end{tabular}

Note: The diagonal elements in bold represent the square roots of the average variance extracted (AVE). Elements outside the diagonal are the correlations between the constructs. Significant at the level of ${ }^{\star} 0.05$ and ${ }^{* *} 0.01$.

Legend: DJ=Distributive Justice; PJ=Procedural Justice; EE=Emotional Exhaustion; DEP=Depersonalization; LPA=Low Personal Accomplishment; JOS=Job Satisfaction; TNI=Turnover Intentions; ACEC=Affective Commitment-Emotional Connection; ACM=Affective Commitment-Meaning

verified that each construct differs from the others in terms of capturing exclusive phenomena. The cross loadings analysis also indicates that the factor loadings are higher in the latent variables than in the others, and that each item is explained by its construct. The model was also verified as being adequate and the answers reliable, since the Cronbach's alpha (internal reliability) and composite reliability are both greater than 0.70 .

Note that organizational justice (DJ and PJ) is positively associated with job satisfaction and affective organizational commitment (emotional connection and meaning) and negatively associated with turnover intentions. The dimensions of organizational justice are negatively associated with burnout in its three dimensions (EE, DEP, and LPR). These results indicate that the higher the self-perception of organizational justice, the lower the incidence of burnout, leading to higher levels of job satisfaction and commitment to the organization and lower turnover intentions.

The Variance Inflation Factors (VIFs) were analyzed using SmartPLS to verify the existence of multicollinearity problems between the variables. The results indicated the absence of multicollinearity between the latent variables, since all VIF values were lower than 5 (Hair Jr et al., 2016). The model has a Standardized Root Mean Squared Residual (SRMR) of 0.080, indicating a good model fit.
Thus, the measurement model is inferred to be adequate, since the constructs were considered reliable and were valid for analysis in the structural model.

\subsection{Evaluation of the structural model}

In order to assess the validity of the structural model, the following were verified: the size and significance of the path coefficients; the Pearson's coefficients of determination (R2), the predictive relevance (Q2), and the effect size (F2) of the constructs (Hair Jr et al., 2016). These data are analyzed using bootstrapping (path, t-value, p-value, and R2) and the blindfolding module (F2 and Q2). For these techniques, the two-tailed test was performed at the significance level of 5\% (bias-corrected and accelerated), with 5,000 interactions (Hair Jr et al., 2016). Table 2 shows the results obtained.

Only procedural justice $\left(\mathrm{H}_{1 b}\right)$ was found to have significant relationships with burnout. There is support for confirming the hypothesis of the effects of burnout on attitudes and behaviors at work. Job satisfaction is negatively affected by emotional exhaustion and low personal accomplishment $\left(\mathrm{H}_{2 \mathrm{a}}\right)$; turnover intentions are positively affected by emotional exhaustion and depersonalization $\left(\mathrm{H}_{2 \mathrm{c}}\right)$; affective organizational commitment with an emotional connection is negatively affected by 
Table 2

\section{Results of the structural model and hypotheses}

\begin{tabular}{|c|c|c|c|c|c|}
\hline Hipótese & Path & Coef. & Mistake & t-value & p-value \\
\hline \multirow{3}{*}{$\mathrm{H}_{1 \mathrm{a}}$} & $\begin{array}{c}\text { Distributive Justice } \rightarrow \text { Emotional } \\
\text { Exhaustion }\end{array}$ & -0.073 & 0.132 & 0.558 & 0.577 \\
\hline & Distributive Justice $\rightarrow$ Depersonalization & -0.046 & 0.129 & 0.356 & 0.722 \\
\hline & $\begin{array}{c}\text { Distributive Justice } \rightarrow \text { Low Personal } \\
\text { Accomplishment }\end{array}$ & -0.030 & 0.146 & 0.203 & 0.839 \\
\hline \multirow{3}{*}{$\mathrm{H}_{1 \mathrm{~b}}$} & $\begin{array}{c}\text { Procedural Justice } \rightarrow \text { Emotional } \\
\text { Exhaustion }\end{array}$ & -0.375 & 0.143 & 2.625 & 0.009 \\
\hline & Procedural Justice $\rightarrow$ Depersonalization & -0.272 & 0.136 & 1.998 & 0.046 \\
\hline & $\begin{array}{l}\text { Procedural Justice } \rightarrow \text { Low Personal } \\
\text { Accomplishment }\end{array}$ & -0.262 & 0.157 & 1.670 & 0.095 \\
\hline \multirow{3}{*}{$\mathrm{H}_{2 \mathrm{a}}$} & $\begin{array}{c}\text { Emotional Exhaustion } \rightarrow \text { Job } \\
\text { Satisfaction }\end{array}$ & -0.266 & 0.100 & 2.654 & 0.008 \\
\hline & Depersonalization $\rightarrow$ Job Satisfaction & 0.022 & 0.098 & 0.228 & 0.820 \\
\hline & $\begin{array}{c}\text { Low Personal Accomplishment } \rightarrow \text { Job } \\
\text { Satisfaction }\end{array}$ & -0.458 & 0.081 & 5.654 & 0.000 \\
\hline \multirow{6}{*}{$\mathrm{H}_{2 \mathrm{~b}}$} & $\begin{array}{l}\text { Emotional Exhaustion } \rightarrow \text { Affective } \\
\text { Commitment-Emotional Connection }\end{array}$ & -0.275 & 0.110 & 2.505 & 0.012 \\
\hline & $\begin{array}{l}\text { Low Personal Accomplishment } \rightarrow \\
\text { Affective Commitment-Emotional } \\
\text { Connection }\end{array}$ & 0.179 & 0.084 & 2.143 & 0.032 \\
\hline & $\begin{array}{c}\text { Depersonalization } \rightarrow \text { Affective } \\
\text { Commitment-Emotional Connection }\end{array}$ & -0.423 & 0.102 & 4.151 & 0.000 \\
\hline & $\begin{array}{l}\text { Emotional Exhaustion } \rightarrow \text { Affective } \\
\text { Commitment-Meaning }\end{array}$ & -0.156 & 0.097 & 1.605 & 0.109 \\
\hline & $\begin{array}{l}\text { Depersonalization } \rightarrow \text { Affective } \\
\text { Commitment-Meaning }\end{array}$ & -0.189 & 0.106 & 1.786 & 0.074 \\
\hline & $\begin{array}{c}\text { Low Personal } \\
\text { Accomplishment } \rightarrow \text { Affective } \\
\text { Commitment-Meaning }\end{array}$ & -0.234 & 0.090 & 2.610 & 0.009 \\
\hline \multirow{3}{*}{$\mathrm{H}_{2 \mathrm{c}}$} & $\begin{array}{c}\text { Emotional Exhaustion } \rightarrow \text { Turnover } \\
\text { Intentions }\end{array}$ & 0.302 & 0.077 & 3.927 & 0.000 \\
\hline & $\begin{array}{c}\text { Depersonalization } \rightarrow \text { Turnover } \\
\text { Intentions }\end{array}$ & 0.386 & 0.087 & 4.422 & 0.000 \\
\hline & $\begin{array}{c}\text { Low Personal Accomplishment } \rightarrow \\
\text { Turnover Intentions }\end{array}$ & 0.044 & 0.064 & 0.693 & 0.488 \\
\hline
\end{tabular}

emotional exhaustion and depersonalization, but positively affected by low personal accomplishment $\left(\mathrm{H}_{2 \mathrm{~b}}\right)$; and the affective organizational commitment with meaning is negatively affected by depersonalization and low personal accomplishment $\left(\mathrm{H}_{2 \mathrm{~b}}\right)$.

Hypothesis $\mathrm{H}_{3}$ was analyzed according to the precepts of Baron and Kenney (1986) and suggestions by Hayes (2013). The direct, indirect, and total effects of the model were analyzed through bootstrapping, estimating the components that constitute the indirect effects. The indirect effects were calculated based on the product of the interactions of $\mathrm{IV} \rightarrow \mathrm{MV}$ and $\mathrm{MV} \rightarrow \mathrm{DV}$, with the output grouping all MV values, in this case the burnout construct, consisting of the EE, DESP, and LPA dimensions. Table 3 shows these effects.

It is observed that burnout only significantly influences the interactions between procedural justice and organizational behaviors. Complete mediation of burnout is observed in the relationship between procedural justice and affective organizational commitment (emotional connection and meaning) $(\mathrm{p}<0.05)$ and satisfaction $(\mathrm{p}<0.1)$. The turnover intentions variable was not significant when analyzed in an integrated manner (as a second-order construct).

The Sobel test was performed to assess which dimensions of burnout were able to confirm the mediation 
Test of mediations $-\mathrm{H}_{3}$

\begin{tabular}{|c|c|c|c|c|c|c|}
\hline \multicolumn{3}{|c|}{ Direct Effect } & \multicolumn{2}{|c|}{ Indirect Effect } & \multicolumn{2}{|c|}{ Total Effect } \\
\hline Path & Coef. & T-value & Coef. & T-value & Coef. & T-value \\
\hline $\mathrm{DJ} \rightarrow$ Burnout $\rightarrow$ JOS & 0.240 & $2.363^{* *}$ & 0.032 & 0.360 & 0.272 & $1.835^{*}$ \\
\hline $\mathrm{DJ} \rightarrow$ Burnout $\rightarrow \mathrm{TNI}$ & -0.304 & $3.807^{* * * *}$ & -0.041 & 0.484 & -0.345 & $2.904^{* * *}$ \\
\hline DJ $\rightarrow$ Burnout $\rightarrow$ ACEC & -0.095 & 0.867 & 0.034 & 0.484 & -0.060 & 0.481 \\
\hline $\mathrm{DJ} \rightarrow$ Burnout $\rightarrow \mathrm{ACM}$ & 0.182 & $1.723^{*}$ & 0.027 & 0.390 & 0.209 & $1.692^{*}$ \\
\hline $\mathrm{PJ} \rightarrow$ Burnout $\rightarrow \mathrm{JOS}$ & 0.025 & 0.235 & 0.214 & $2.161^{* *}$ & 0.239 & $1.690^{*}$ \\
\hline $\mathrm{PJ} \rightarrow$ Burnout $\rightarrow \mathrm{TNI}$ & 0.035 & 0.367 & -0.230 & $2.330^{* *}$ & -0.194 & 1.492 \\
\hline $\mathrm{PJ} \rightarrow$ Burnout $\rightarrow$ ACEC & 0.159 & 1.512 & 0.171 & $2.078^{* *}$ & 0.331 & $2.994^{* *}$ \\
\hline $\mathrm{PJ} \rightarrow$ Burnout $\rightarrow \mathrm{ACM}$ & 0.096 & 0.869 & 0.171 & $2.049^{* *}$ & 0.267 & $2.162^{* *}$ \\
\hline
\end{tabular}

Note: Significant at the level of ${ }^{\star} 0.1 ;{ }^{\star \star} 0.05 ;{ }^{\star * \star} 0.01 ;{ }^{\star * \star} 0.000$.

Legend: DJ=Distributive Justice; PJ=Procedural Justice; JOS=Job Satisfaction; TNI=Turnover Intentions; ACEC=Affective Commitment-Emotional Connection; ACM=Affective Commitment-Meaning

of the model. This was confirmed by the total specific indirect effects using bootstrapping. These processes indicated that: (i) the emotional exhaustion dimension mediates the relationship between procedural justice and both job satisfaction $(\beta 0.100, \mathrm{p}<0.061)$ and affective commitment with an emotional connection ( $\beta 0.103$, $\mathrm{p}<0.067$ ); (ii) depersonalization mediates the interactions between procedural justice and affective commitment with an emotional connection ( $\beta 0.115, \mathrm{p}<0.08)$; and (iii) low personal accomplishment mediates the interactions between procedural justice and job satisfaction $(\beta 0.120$, $\mathrm{p}<0.099)$.

These findings indicate that the auditors' job satisfaction and affective organizational commitment will be higher when levels of emotional exhaustion, depersonalization, and low personal accomplishment are minimized by procedures in the organization that are perceived as fair. In addition, the tests show that the turnover intentions variable is mediated by the dimensions of emotional exhaustion $(\beta-0.113, p<0.041)$ and depersonalization $(\beta-0.105, \mathrm{p}<0.079)$. This result suggests that turnover intentions will only occur when individuals feel they are in a state of depersonalization, caused by feelings of procedural injustice. Low personal accomplishment itself may not cause individuals to have such a dysfunctional attitude/behavior.

Contrary to what was expected, there was no mediation of distributive justice in attitudes and behaviors at work. There were significant direct relationships with turnover intentions, job satisfaction, and affective organizational commitment, with no residual influence of burnout. This indicates that perceiving fair distribution directly leads to job satisfaction (Adams, 1965), lower turnover intentions, and a greater affective connection with the organization (Tepper, 2001).

The Pearson's coefficients of determination (R2) indicated quality and explanatory power of the structural model. Strong explanatory effects were found for turnover intentions, job satisfaction, and affective organizational commitment, moderate effects were found for emotional exhaustion, and little effects were found for depersonalization and low personal accomplishment. The quality of prediction of the model (Q2) was greater than zero for all constructs (Hair Jr et al., 2013). The effect size test (F2), which assesses a construct's ability to explain the model, also revealed that all constructs have strong effects and assist in adjusting the model (Hair Jr et al., 2013).

\subsection{Discussion of results}

The results of the survey of internal auditors show negative relationships between procedural justice and the dimensions of burnout (emotional exhaustion, low personal accomplishment, and depersonalization), which enables the acceptance of hypothesis $\mathrm{H}_{1 \mathrm{~b}}$. These findings are consistent with those of Maslach et al. (2001) and suggest that companies that explain the procedures affecting their employees can reduce feelings of exhaustion. In contrast, organizations that do not promote confidence in the workplace create a basis for burnout (Kalbers \& Fogarty, 2005).

Depersonalization interacts significantly with procedural justice. Employees will exhibit cynical, selfish actions when the decision-making processes are perceived as unfair. The relationship between the dimension of 
low personal accomplishment and procedural justice indicates that interpersonal relationships impact people's behavior and attitudes (Moorman, 1991), and may result in inefficiency, low motivation, and reduced self-esteem (Fogarty et al., 2000). Employees who feel they have not had the opportunity to grow or prove their competence in the organization are unlikely to feel loyal or positively identify with the processes adopted by the organization (Campbell et al., 2013).

Contrary to what was expected, as in the work of Folger and Konovsky (1989), the internal auditors in the sample seem to pay less attention to the fair distribution of remuneration. This factor appears to be insufficient to explain the dimensions of burnout $\left(\mathrm{H}_{\mathrm{la}}\right)$ and emotional exhaustion, depersonalization, and low personal accomplishment. Folger and Cropanzano (1998) suggest that people are not only concerned about the results of distributions, but also about the procedures in place for carrying out these distributions. Deconinck and Stilwell (2010) emphasize that remuneration can be a secondary factor, while the methods used for allocating payments, the tasks, and the relationships with supervisors may be more relevant in terms of generating feelings of injustice at work. Auditors seem to be mainly affected by how organizations are able to meet their need for personal growth and development (Muliawan, Green, \& Robbos, 2009), for example with policies and career plans that make them feel they are not adversely and unfairly treated.

The expected interactions between burnout and organizational behavior were supported. The three dimensions of burnout, according to Lee and Ashforth (1996), are negatively related to job satisfaction $\left(\mathrm{H}_{2 \mathrm{a}}\right)$ and affective organizational commitment $\left(\mathrm{H}_{2 \mathrm{~b}}\right)$, and positively related to turnover intentions $\left(\mathrm{H}_{2 \mathrm{c}}\right)$. The emotional exhaustion dimension is related to the three behaviors at work. This indicates that the auditors' feelings of exhaustion due to excessive psycho-emotional demands (Fogarty et al., 2000), resulting from tasks that require innovative and creative solutions, time pressures, and high levels of responsibility, are reflected in satisfaction at work, affective commitment, and turnover intentions (Maslach et al., 2001).

The depersonalization dimension affects turnover intentions and affective organizational commitment to the organization, in terms of emotional connection and meaning. When employees distance themselves from others as a form of emotional defense (Maslach et al., 1996), this is reflected in negative conditions at work.
When they suffer from depersonalization, they tend to become less loyal to their employer, which can generate feelings of not belonging and less identification with the organization (Campbell et al., 2013).

The dimension of low personal accomplishment, which refers to perceptions of an inability to deal with tasks, has a negative impact on job satisfaction and affective commitment in terms of emotional connection and meaning. The result suggests that auditors who have this perception tend to feel less satisfaction in the work environment and less dedication and ability to identify with the organization and its objectives (Mowday et al., 1979). However, contrary to what was expected, it seems that individuals with low personal accomplishment, who tend to negatively evaluate themselves and are unhappy with their personal and professional development (Maslach \& Jackson, 1981), did not present any less emotional connection with the organization (sense of bonding and integration with the organization) (Meyer et al., 1993). Therefore, this result requires further investigation.

The analysis of hypothesis $\mathrm{H}_{3}$ shows that burnout only mediates the relationship between procedural justice and both affective organizational commitment (meaning) and job satisfaction. This indicates that how organizational policies are carried out and how information is shared can affect employees' motivation (Silva \& Caetano, 2016). The use of fair procedures creates expectations of fair treatment and, consequently, positive feelings, loyalty to the organization, and strengthened interpersonal ties (Cropanzano \& Greenberg, 1997).

The dimensions of emotional exhaustion and depersonalization can more strongly explain the mediating effects of the constructs. In line with previous studies, perceptions of organizational justice seem to be strongly linked to the central dimension of burnout, to exhaustion, and, subsequently, to depersonalization (Maslach et al., 2001). Fogarty et al. (2000) found evidence of a considerable degree of emotional exhaustion and depersonalization among accounting professionals. In line with the findings of Vaamonde et al. (2018), they were also able to significantly explain that individuals who perceive greater equity in their organizational exchanges and reciprocity have lower levels of burnout and turnover intentions.

Contrary to what was predicted $(\mathrm{H} 3)$, the relationship between perceptions of distributive justice and the results did not indicate that burnout acts as a mediating variable. It merely showed that the effects of balanced distribution lead to a direct increase in job 
satisfaction and affective commitment in terms of meaning and a direct reduction in intentions to leave the company (Folger \& Cropanzano, 1998). Perceptions of distributive injustice seem to be less stressful than procedural injustice. The work environment of internal audit professionals is recognized for its high workload, tight deadlines, and demand for skills and technical knowledge (Larson, 2004; Kalbers \& Fogarty, 2005). Even though audit activities are stressful and the remuneration can (directly) lead to dysfunctional attitudes and behaviors, audit professionals seem to be more impacted by organizational policies and processes in terms of the attribution and exercise of their functions (Muliawan et al., 2009).

In general, the results indicate that perceived injustice regarding the formal processes of an organization causes stronger responses at work than the distributive processes. This emphasizes the relevance of the implicit values of organizational processes and structures and their ability to shape emotional and cognitive reactions to work (Maslach et al., 2001). Greater procedural fairness supports the development of relationships in which there is greater trust, loyalty, and a connection with the organization (Colquitt et al., 2001). Thus, organizations that share the criteria adopted in the processes that impact the routines of their employees and that engage in cordial interpersonal treatment, tend to have lower levels of perceived organizational injustice, which minimizes the burnout process and positively impacts their operations (Maslach \& Jackson, 1984).

\section{Final Considerations}

This study investigated the extent to which organizational justice, burnout, and work attitudes and behaviors (job satisfaction, affective organizational commitment, and turnover intentions) are related, and revealed that distributive justice affects the latter directly while procedural justice affects them through the mediation of burnout. It is concluded that the attitudes and behaviors of internal auditors at work tend to be more positive when the distributions of resources are perceived as being fair and the formal processes of the organization do not cause stress or, consequently, burnout.

\section{I Theoretical implications}

This study makes theoretical contributions in terms of exploring how perceptions of organizational justice are able to psychologically influence individuals' attitudes and behaviors in a positive way (greater job satisfaction and affective organizational commitment) or create dysfunctional ones (turnover intentions) in the organizational environment. It helps to explore the background of the variables that affect work and factors that can lead to burnout. Thus, it amplifies the discussions about attitudes of initiative and social interaction, as well as passive attitudes resulting from physical and mental exhaustion and from indifference to the work, which may arise based on judgments about the distribution of resources, decision-making processes, and interactions with supervisors (Maslach et al., 2001). Another contribution is its discussion on the effects of burnout, whose interactions in the organizational context are less explored than in the areas of health and education.

\subsection{Practical implications}

The present study contains practical contributions for organizations and auditing professionals as it demonstrates that perceptions of organizational (in)justice and a state of burnout can have dysfunctional consequences and affect results. Organizations can try to prevent the onset of this syndrome by reducing employees' negative emotions regarding procedural issues and by creating an environment that is perceived as fair. Perceptions of organizational injustice can be reduced through a more open system, giving voice to employees, and favoring a greater level of knowledge and involvement in the processes that lead to the results of the organization. Greater sharing of internal information can lead to better interpersonal interactions and minimize factors that lead to leaving the organization. Indicative studies on job satisfaction levels could identify employees' feelings about the functions they perform and the work environment, and would serve to diagnose broader problems in the organization and its formal processes.

\subsection{Limitations and suggestions for future research}

Possible limitations of this cross-sectional research relate to common method bias, self-assessment, the rates of participant responses, and the halo effect. However, the results did not indicate a common method bias. Also, non-response bias tests validated the information obtained by the research instruments, all measured on diffuse multidimensional scales, which makes self-assessments less susceptible to the halo effect. The reliability and 
multicollinearity tests also indicated that the answers can be considered consistent. However, the study focused on the perception of organizational justice as an antecedent to burnout. Other organizational variables can help explain the phenomena that trigger or mitigate these symptoms, such as participation, involvement, and organizational trust. Moreover, this study did not analyze the consequences of attitudes and behaviors at work, such as performance, which can be affected by job (in)satisfaction and by affective organizational commitment.

\section{References}

Adams, J.S. (1965). Inequity in social exchange. Advances in Experimental Social Psychology, 2, 267-299.

Almeida, G.O., \& Silva, A.M.M. (2006). Justiça organizacional, impactos no burnout e o comprometimento dos trabalhadores. Revista Eletrônica de Gestão Organizacional, 4(2), 160-175.

Baron, R.M., \& Kenny, D.A. (1986). The moderatormediator variable distinction in social psychological research: Conceptual, strategic, and statistical considerations. Journal of Personality and Social Psychology, 51(6), 1173-1182.

Benevides-Pereira, A.M.T. (2003). O estado da arte do burnout no Brasil. Revista Eletrônica Interação Psy, 1(1), 4-11.

Bies, R.J., \& Moag, J.F. (1986). Interactional justice: Communication criteria of fairness. In: R.J. Lewicki, B.H. Sheppard, \& M.H. Bazerman (Eds.). Research on negotiations in organizations (vol. 1, pp. 43-55). Greenwich, CT: JAI Press.

Campbell, N.S., Perry, S.J., Maertz, C.P., Allen, D.G., \& Griffeth, R.W. (2013). All you need is... resources: The effects of justice and support on burnout and turnover. Human Relations, 66(6), 759-782.

Choi, S. (2011). Organizational justice and employee work attitudes: the federal case. The American Review of Public Administration, 41(2), 185-204.

Cohen-Charash, Y., \& Spector, P.E. (2001). The role of justice in organizations: A meta-analysis. Organizational Behavior and Human Decision Processes, 86(2), 278-321.
Colquitt, J.A., Conlon, D.E., Wesson, M.J., Porter, C.O.L.H., \& Ng, K.Y. (2001). Justice at the millennium: A meta-analytic review of 25 years of organizational justice research. Journal of Applied Psychology, 86(3), 425-445.

Cropanzano, R., Bowen, D.E. \& Gilliland, S.W. (2007). The management of organizational justice. Academy of Management, 21 (4), 34-48.

Cropanzano, R., Goldman, B.M., \& Benson, L. (2005). Organizational justice. In: J. Barling, E.K. Kelloway, \& M.R. Frone. Handbook of work stress (pp. 63-88). Sage, Thousand Oaks.

Cropanzano, R., \& Greenberg, J. (1997). Progress in organizational justice: Tunneling through the Maze. In: C.L. Cooper, \& I.T. Robertson (Eds.). International review of industrial and organizational psychology (Vol. 12, pp. 317-372). John Wiley \& Sons, New York.

Deconinck, J.B., \& Stilwell, C.D. (2004). Incorporating organizational justice, role states, pay satisfaction and supervisor satisfaction in a model of turnover intentions. Journal of Business Research, 57(3), 225-231.

Filenga, D., \& Siqueira, M.M.M. (2006). O impacto de percepçôes de justiça em três bases de comprometimento organizacional. Revista de Administração, 41(4), 431-441.

Flint, D., Haley, L.M., \& McNally, J.J. (2013). Individual and organizational determinants of turnover intent. Personnel Review, 42(5), 552-572.

Fogarty, T.J., Singh, J., Rhoads, G.K., \& Moore, R.K. (2000). Antecedents and consequences of burnout in accounting: Beyond the role stress model. Behavioral Research in Accounting, 12(1), 31-67.

Folger, R., \& Cropanzano, R. (1998). Organizational justice and human resource management. Sage, Beverly Hills.

Folger, R., \& Konovsky, M.A. (1989). Effects of procedural and distributive justice on reactions to pay decisions. Academy of Management Journal, 32(1), 115-130.

Fornell, C., \& Larcker, D.F. (1981). Structural equation models with unobservable variables and measurement error: Algebra and statistics. Journal of Marketing Research, 18(3), 382-388. 
Freudenberger, H.J. (1974). Staff burnout. Journal of Social Issues, 30(1), 159-165.

Greenberg, J. (1990). Organizational justice: Yesterday, today, and tomorrow. Journal of Management, 16(2), 399-432.

Greenberg, J. (2004). Stress fairness to fare no stress: Managing workplace stress by promoting organizational justice. Organizational Dynamics, 33(4), 352-365.

Hair Jr, J.F., Hult, G.T.M., Ringle, C., \& Sarstedt, M. (2016). A primer on partial least squares structural equation modeling (PLS-SEM) (2nd ed.). Sage, Thousand Oaks.

Hayes, A.F. (2013). Introduction to mediation, moderation, and conditional process analysis. The Guilford Press, New York.

Hoppock, R. (1935). Job satisfaction. Harper and Brothers, New York.

Kalbers, L.P., \& Fogarty, T.J. (2005). Antecedents to internal auditor burnout. Journal of Managerial Issues, 12(1), 101-118.

Kahill, S. (1988). Symptoms of professional burnout: A review of the empirical evidence. Canadian Psychology, 29(3), 284-297.

Kuo, H.T., Lin, K.C., \& Li, I.C. (2014). The mediating effects of job satisfaction on turnover intention for longterm care nurses in Taiwan. Journal of Nursing Management, 22(2), 225-233.

Larson, L.L. (2004). Internal auditors and job stress. Managerial Auditing Journal, 19(9), 1119-1130.

Lee, P.C.B. (1996). An investigation of the turnover intentions of information systems staff in Singapore. Thesis, The University of Queensland, St Lucia, QLD.

Lee, R. L., \& Ashforth, B. (1996). A meta-analytic examination of the correlates of the three dimensions of job burnout. Journal of Applied Psychology, 81(2), 123-133.

Leiter, M.P., \& Maslach, C. (2005). A mediation model of job burnout. In: A.-S.G. Antoniou, \& C.L. Cooper (Eds.). New horizons in management: Research companion to organizational health psychology (pp. 544-564). Edward Elgar Publishing, Northampton, MA, US.

Lewin, J.E., \& Sager, J.K. (2007). A process model of burnout among salespeople: Some new thoughts. Journal of Business Research, 60(12), 1216-1224.

Locke, E.A. (1984). Job satisfaction. In: M. Gruneberg, $\&$ T. Wall (Eds.). Social psychology and organizational behavior. John Wiley and Sons, New York.

Maslach, C. (2007). Entendendo o burnout. In: A.M. Rossi, P.L. Perrewé, \& S.L. Sauter (Orgs.). Stress e qualidade de vida no trabalho: Perspectivas atuais da saúde ocupacional (pp. 41-55). Atlas, São Paulo.

Maslach, C., \& Goldberg, J. (1998). Prevention of burnout: News perspectives. Applied \& Preventive Psychology, 7(1), 63-74.

Maslach, C., \& Jackson, S.E. (1981). The measurement of experienced burnout. Journal of Occupational Behavior, 2(2), 99-113.

Maslach, C., \& Jackson, S.E. (1984). Burnout in organizational settings. In: S. Oskamp (Ed.). Applied social psychology annual: Applications in organizational settings (5nd ed., pp. 133-153). Sage, Beverly Hills, CA.

Maslach, C., Jackson, S.E., \& Leiter, M.P. (1996). Maslach Burnout Inventory: Test manual. (3rd ed.). Consult. Psychol. Press, Palo Alto, CA.

Maslach, C., \& Leiter, M.P. (1997). The truth about burnout. Jossey-Bass, San Francisco.

Maslach, C., Schaufeli, W.B., \& Leiter, M.P. (2001). Job burnout. Annual Review of Psychology, 52(1), 397-422.

Mendonça, H., Pereira, C., Tamayo, A., \& Paz, M.G.T. (2003). Validação fatorial de uma escala de percepção de justiça organizacional. Estudos: Saúde e Vida, 30(1), 111-130.

Meyer, J.P., Allen, N.J., \& Smith, C.A. (1993). Commitment to organizations and occupations: Extension and test of a three-component conceptualization. Journal of Applied Psychology, 78(4), 538-551, 1993. 
Mobley, W.H., Horner, S.O., \& Hollingsworth, A.T. (1978). An evaluation of precursors of hospital employee turnover. Journal of Applied Psychology, 63(4), 408-414.

Moliner, C., Martínez-Tur, V., Peiró, J.M., Ramos, J., \& Cropanzano, R. (2005). Relationships between organizational justice and burnout at the work-unit level. International Journal of Stress Management, 12(2), 99-116.

Moliner, C., Martínez-Tur, V., Ramos, J., Peiró, J.M., \& Cropanzano, R. (2008). Organizational justice and extra role customer service: The mediating role of well-being at work. European Journal of Work and Organizational Psychology, 17(3), 327-348.

Mowday, R.T., Steers, R.M., \& Porter, L.W. (1979). The measurement of organizational commitment. Journal of Vocational Behavior, 14(2), 224-247.

Muliawan, A.D., Green, P.F., \& Robb, D.A. (2009). The turnover intentions of information systems auditors. International Journal of Accounting Information Systems, 10(3), 117-136.

Moorman, R.H. (1991). Relationship between organizational justice and organizational citizenship behaviors: Do fairness perceptions influence employee citizenship? Journal of Applied Psychology, 76(6), 845-855.

Podsakoff, P.M., MacKenzie, S.B., Lee, J.-Y., \& Podsakoff, N.P. (2003). Common method biases in behavioral research: A critical review of the literature and recommended remedies. Journal of Applied Psychology, 88(5), 879-903.

Robbins, J.M., Ford, M.T., \& Tetrick, L.E. (2012). Perceived unfairness and employee health: A meta-analytic integration. Journal of Applied Psychology, 97(2), 235-272.
Scheaffer, R.L., Mendenhall, W., \& Ott, R.L. (1996). Elementary survey sampling (5th Ed). Duxbury Press, New York.

Scanlan, J.N., \& Still, M. (2013). Job satisfaction, burnout and turnover intention in occupational therapists working in mental health. Aust Occup Ther J, 60(5), 310-318.

Shkoler, O., \& Tziner, A. (2017). The mediating and moderating role of burnout and emotional intelligence in the relationship between organizational justice and work misbehavior. Revista de Psicologia del Trabajo y de las Organizaciones, 33(2), 157-164.

Silva, M.R., \& Caetano, A. (2016). Organizational justice across cultures: A systematic review of four decades of research and some directions for the future. Social Justice Research, 29(3), 257-287.

Spector, P.E. (1985). Measurement of human service staff satisfaction: Development of the job satisfaction survey. American Journal of Community Psychology, 13(6), 693-713.

Tepper, B.J. (2001). Health consequences of organizational injustice: Tests of main and interactive effects. Organizational Behavior and Human Decision Processes, 86(2), 197-215.

Tett, E.P., \& Meyer, J.P. (1993). Job satisfaction, organizational commitment, turnover intention, and turnover: Path analyses based on meta-analytic findings. Personnel Psychology, 46(2), 259-293.

Vaamonde, J.D., Omar, A., \& Salessi, S. (2018). From organizational justice perceptions to turnover intentions: The mediating effects of burnout and job satisfaction. Europe's Journal of Psychology, 14(3), 554-570. 


\section{Appendix A}

Constructs and statements of the research instruments

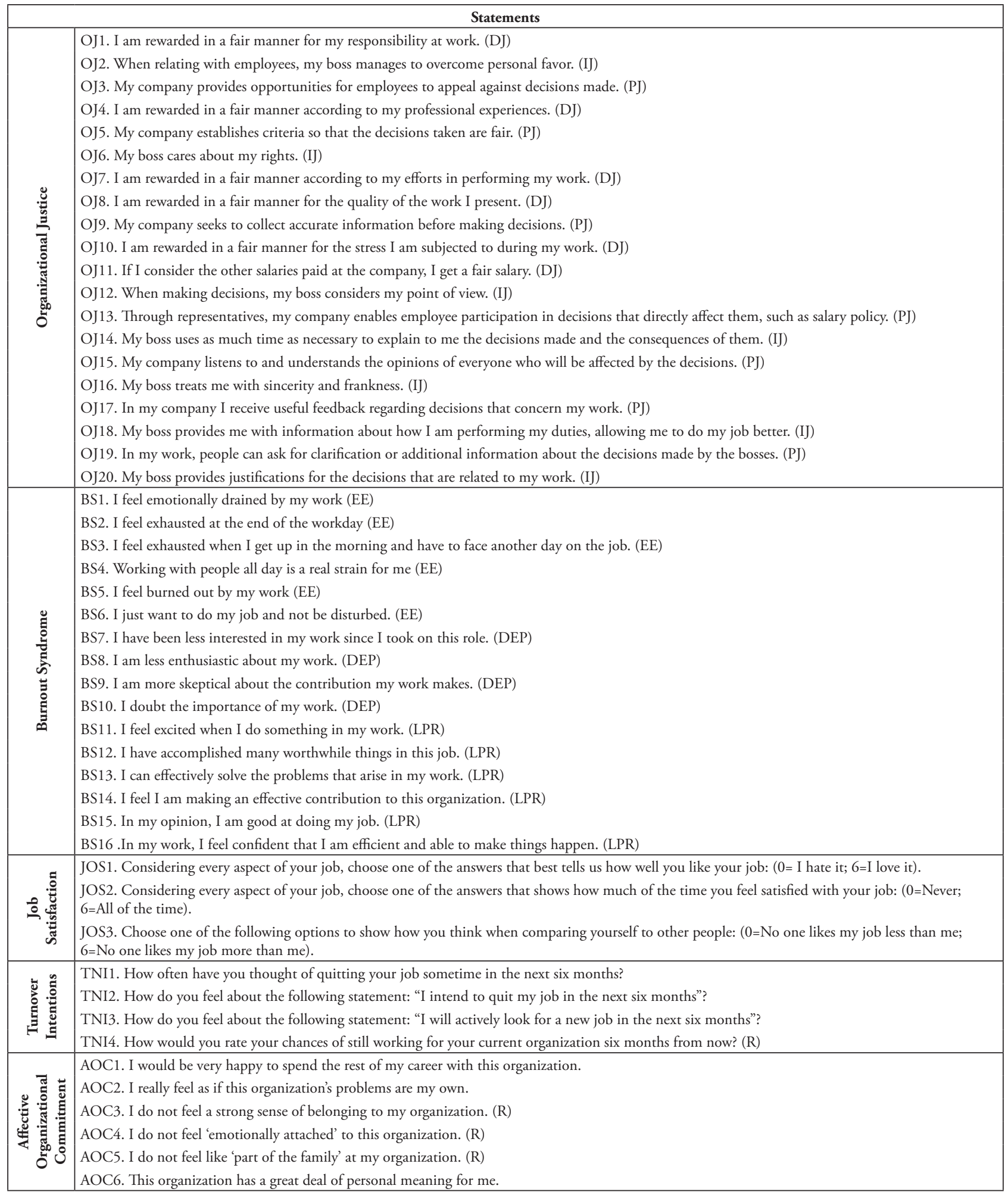

Legend: $(\mathrm{R})=$ Reverse question; OJ=Organizational Justice; DJ=Distributive Justice; PJ=Procedural Justice; IJ=Interactional Justice; BS=Burnout Syndrome; EE=Emotional Exhaustion; DEP=Depersonalization; LPA=Low Personal Realization; JOS=Job satisfaction; TNI=Turnover intentions; AOC=Affective Organizational Commitment. 


\section{Financial support:}

None.

\section{Conflicts of interest:}

None.

\section{Copyrights:}

RBGN owns the copyrights of this published content.

\section{Plagiarism analysis:}

RBGN performs plagiarism analysis on all its articles at the time of submission and after approval of the manuscript using the iThenticate tool.

\section{Authors:}

1. Daniele Cristina Bernd, PhD in Accounting, Federal University of Santa Catarina, SC, Florianópolis, Brazil.

E-mail: dcbernd@hotmail.com

2. Ilse Maria Beuren, PhD in Controllership and Accounting, University of São Paulo, São Paulo, SP, Brazil. Email: ilse.beuren@gmail.com

\section{Authors' Contributions:}

$\mathbf{1}^{\text {st }}$ author: Definition of research problem; Development of hypotheses or research questions (empirical studies); Definition of methodological procedures; Literature review; Data Collection; Statistical analysis; Analysis and interpretation of data; Critical revision of the manuscript; Manuscript writing.

$2^{\text {nd }}$ author: Definition of research problem; Development of hypotheses or research questions (empirical studies); Definition of methodological procedures; Literature review; Analysis and interpretation of data; Critical revision of the manuscript; Manuscript writing. 